\title{
SME cluster vs. multinational companies: similarities and differences for tax and competition lawmakers
}

\author{
Liyang Hou* and Davide Maria Parrilli \\ Interdisciplinary Centre for Law and ICT (ICRI), \\ K.U. Leuven, IBBT, \\ Sint-Michielstraat 6, B-3000 Leuven, Belgium \\ E-mail: liyang.hou@law.kuleuven.be \\ E-mail: davide.parrilli@law.kuleuven.be \\ *Corresponding author
}

\begin{abstract}
The aim of the article is to analyse to what extent some traditional tools developed in the area of tax and competition law for big companies can be applied to SME clusters in order to promote their development. The focus of the research, in particular, will be on group taxation and the EU competition provisions in the fields of abuse of dominant positions and mergers, as well as anti-competitive agreements. Based on the examples coming from some European countries, in particular Italy and on an accurate review on literature and legislation, it will be shown that the extension of group taxation and the non-expansion of competition tools to SME clusters are efficient ways to promote their growth and development.
\end{abstract}

Keywords: SME clusters; tax; competition law; private law.

Reference to this paper should be made as follows: Hou, L. and Parrilli, D.M. (2009) 'SME cluster vs. multinational companies: similarities and differences for tax and competition lawmakers', Int. J. Private Law, Vol. 2, No. 4, pp.400-411.

\begin{abstract}
Biographical notes: Liyang Hou obtained his Law Degree (Hons.) at the Beijing Institute of Technology (Beijing) in 2001 and his Master of Law (Hons.) at the China University of Politics and Law (Beijing) in 2004. In 2007, he earned his LLM (magna cum laude) in European Union Law at the Katholieke Universiteit Leuven (Belgium). Currently, he is a $\mathrm{PhD}$ candidate at Faculty of Law, KU Leuven.

Davide Maria Parrilli obtained his Law Degree at the University of Padova (Italy) in 2005 and LLM (cum laude) at the University of Tilburg (The Netherlands) in International and European Business Law. Now he is working at ICRI - IBBT, KU Leuven where he is conducting research on ICT law from the business point of view.
\end{abstract}

\section{Introduction}

Small and medium enterprises (SMEs) are undoubtedly very important actors in the European trade and economy, both in quantitative and qualitative terms. As regards the former aspects, SMEs represent $99.8 \%$ of all enterprises located in the European Union 
(EU) and they employ more than two thirds of the overall workforce (Eurostat, 2008). With regards to the qualitative aspects, it has been pointed out that the role of SMEs in the European society has become increasingly important as providers of employment opportunities and key players for the wellbeing of the communities at local and regional level (European Commission, 2008). At the same time, it will be no longer possible to ignore their impact on economy given the fact that actually the average firm's size is decreasing (Vermeulen, 2003) and therefore, the European business scene will be occupied predominantly by SMEs.

As a preliminary remark, this article necessarily builds on the definition of SME adopted by the European Commission in 2003 (Commission Regulation of 6 May 2003 concerning the definition of micro, SMEs, 2003/361/EC, OJ L 124, 20.5.2003, pp.36-41). According to which (Article 2.1), 'the category of micro, SMEs is made up of enterprises which employ fewer than 250 persons and which have an annual turnover not exceeding EUR 50 million and/or an annual balance sheet total not exceeding EUR 43 million'.

Another pivotal aspect to take into account from the political, economic and legal point of view is the cooperation between SMEs within a cluster (please be aware that up to the ends of the research, the terms 'clustering', 'cooperation' and 'networking' are synonymous). The concept of SME cluster is ideally a step further than isolated SMEs (at least in a purely theoretical scenario) and clusters have been authoritatively defined in the literature as:
"Geographic concentrations of interconnected companies and institutions in a particular field. Clusters encompass an array of linked industries and other entities important to competition. They include, for example, suppliers of specialised inputs such as components, machinery and services, and providers of specialised infrastructures. Clusters also often extend downstream to channels and customers and laterally to manufacturers of complementary products and to companies in industries related by skills, technologies or common inputs." (Porter, 1998)

In this article the authors will report some of the findings of the FP-6 European funded Project Effort (contract no. 035088) whose aim is to determine whether extended (i.e., transnational) and dynamic (i.e., able to address rapidly changing environments) clustering can be an enabler to economic growth in Europe. Cooperation is perceived to be one of the key elements to enhance competitiveness at worldwide level and it has been stressed out that the main use of cooperative networks consists of providing information that otherwise would be too difficult and expensive to obtain as an individual company and furthermore, economies of scale can be achieved if the cooperative network extends to common business policies (Pinto Barcellos et al., 2008).

The benefits of clustering are therefore very extended (Porter, 1998) and as pointed out in the literature, provided that in the EU consensus has been reached on the role of SMEs and of SME clusters in growth, competitiveness, innovation and employment, in the last years political interest in these kinds of business structures has grown, particularly in light of Lisbon Agenda: 


\begin{abstract}
"Which undertook to generate a favourable environment for the creation and development of innovative enterprises and particularly SMEs. European policies and programmes aim to contribute to the development of entrepreneurial dynamics to facilitate the creation, growth and development of enterprises as well as their innovative capacity and their ability to access new markets and to adapt to the new economy." (Aernoudt, 2003).
\end{abstract}

The above policies, basically, concern also SME clusters and in the following lines, it will be shown to what extent two specific branches of law, i.e., taxation and competition regulations, can be enablers to the expansion and growth of clusters. Both tax and competition law have in common the fact to have been originally addressed, at least to some extent, mainly or exclusively, to big companies. In other words, SMEs, individually or clustered, were perceived as not relevant enough and no remarkable taxation or competition policies have been set up at national or European level to promote their growth and their mutual collaboration. As regards tax law, the reason for this phenomenon is that big companies are usually able to create notable taxable profits while in competition law, only companies with a certain degree of market power are prone to distort competition in the relevant market(s).

The authors of this article adopt a different approach to the relations between taxation, competition and SME clusters and they will address this issue from the 'positive' point of view. In other words, they will show, with an analysis of the existing European sources and/or national legislations, to what extent tax and competition law can be enablers to SME cooperation. It is very interesting to anticipate here the outcomes of the analysis and state that such an objective can be reached by tax and competition law in different ways. The main questions are:

1 whether and how traditional taxation and competition tools and rules developed by the lawmakers for big companies (often groups of companies) can be efficiently applied to cooperating SMEs and from a different point of view

2 whether such clusters can benefit from the (non-)extension of these instruments.

\title{
2 Tax law as enabler to SME clusters: group taxation for clusters
}

The tax lawmakers traditionally focused their attention on big companies, especially multinational enterprises (MNEs), for their undoubted capability to create innovation and sustain the growth of a country, especially in the first decades after the Second World War (Parrilli, 2008). SMEs therefore were not the object of specific massive policies aimed to sustain their formation and expansion and this allowed them, at the same time, not to be affected (not always positive) by the intervention of state and regional authorities and to set up efficient and original forms of collaboration.

It is theoretically possible to indicate a wide plurality of instruments that can act as enablers to SME clusters and it is particularly interesting to explore the feasibilities of the application of some taxation 'tools' developed for big companies (to be more precise, for business entities bigger than isolated SMEs) to clustered SMEs, notably the group taxation. With this expression we mean that a group of companies (thus, a structure characterised by vertical integration, i.e., relations of control/ownership, as opposed to clusters that have a predominantly 'horizontal' dimension dominated by collaboration inter pares) is considered to be a single entity from the fiscal point of view for the very 
fact that it forms a single economic unit. Therefore, the tax system provides groups of companies (at least to some extent) with the same treatment as businesses that operate through separate branches. In the former case, a group is composed of several legal persons, while in the latter situation only one legal entity is involved (European Commission, 2006).

Group taxation (or tax treatment of fiscal unity) has been created for bigger business entities structured as a group, so that profits and losses of the companies that form the group can be mutually offset, which can be a relevant advantage for the group as a whole (Jarass and Obermair, 2006). Since the objective of this article is to show the extent of how some traditional legal tools directed to big companies can be successfully applied to SME clusters, it is surely interesting to analyse whether group taxation may be the case in point. The best example in Europe is the Italian legislation regarding taxation of clusters which demonstrates that the phenomenon of clustering is extremely important in this country (Callegati and Grandi, 2005; Bagnasco, 1977; Porter, 1998).

The Law No. 266 of 23 December 2005 introduced a (potentially) revolutionary reform in the taxation of clusters ('distretti produttivi', in English: productive districts) with the aim to give them two different possibilities:

1 Unitary corporate taxation (so-called consolidated taxation) of the firms that form the cluster, based on the sum of the profits or losses of the members and according to the rules for the national group taxation (Article 1,368, 1) which, as set forth by

Articles 117-129 of the Italian Income Tax Consolidation Act, allows all or some of the companies of the group to tax their income on a unitary basis, which is determined by the holding with full offset of profits and losses generated by the different entities and which, if adopted by the cluster, cannot be repealed for a period of three fiscal years. From a different point of view it is not really clear from the text of the law, despite the different assumptions of the literature (Lenoci et al., 2006), whether it is possible that only some of the firms of the cluster adhere to it, like in the case of national group taxation.

2 Unitary taxation through agreements with the national and local tax authorities as regards the amount of taxes to pay (Article 1, 368,6) where the cluster concerned agrees with the national (for income taxation) and local (for other taxes) competent authorities the amount of taxes to pay for at least thee years and then, the cluster itself divides the respective quota of taxes between the different members.

This reform is undoubtedly a good vehicle to sustain SME clusters development and an invitation for them to be more ambitious; in other words, to act as bigger economic players and at the same time to keep the typical flexibility of smaller firms. Nevertheless, there are some major problems linked to the implementation of the 2005 amendments, which must be solved by the lawmaker.

The first issue is related to the individuation of the clusters that can benefit from the unitary taxation. With this regard Law No. 266 states that the criteria of individuation shall be specified by a decree to be enacted, basically, by several governmental departments together. However, the concerned authorities have not yet drafted such a decree. In general terms, the 'distretti produttivi' is defined as 'free aggregations of firms articulated on territorial and functional basis with the objective to improve the organisational and productive efficiency, according to principles of vertical and horizontal subsidiarity, also in collaboration with the organisations of employers' 
(Article 1, 366). This definition is rather obscure and unclear. Moreover, two other earlier attempts were made by the Italian legislator to define the notion of cluster with different names. The first source to address clusters was the Law No. 317 of 5 October 1991 (Article 36, 1), which was developed into the notion of 'distretti industriali' (in English: industrial districts). A few years later, the Law No. 140 of 11 May 1999 (Article 6, 8) created another concept, quite similar to that of industrial district, i.e., the 'sistemi produttivi locali' (in English: local productive systems). It is beyond the scope of this article to discuss whether there exist real differences between the three above notions. It is possible to strongly support the opinion that until the lawmaker finally adopts a unique legal concept of cluster, it is suitable to interpret the 'distretti produttivi' to include (to the ends of the unitary taxation) the 'distretti industriali' and the 'sistemi produttivi locali'. From the practical point of view, it is necessary to point out that the individuation of the 'industrial districts' and of the 'local productive systems' is left to the regional authorities (Cardi et al., 2006) and therefore we will not exclude the direct applicability of the unitary taxation to the clusters already listed by the regions provided that there is no need for the decree mentioned in Article 1(366) of the Law No. 266.

The second problem is more radical and affects also the other potential countries that wish to enact a tax reform similar to the Italian one and consists precisely in the legal notion of cluster to the ends of taxation. Taking into account that the unitary taxation gives some powers to a member of the cluster (e.g., to represent the other companies before the tax authorities, to submit the unitary tax declaration, to offset profits and losses of the members of the cluster, etc.), it is necessary to assess on which grounds these powers are conferred to such a company. In case of group taxation, the above tasks are fulfilled by the holding, provided his role of 'corporate supremacy' (i.e., control) is clear in the group. Nevertheless, the concept of control as such does not characterise the cluster that represents a 'new spatial organisational form in between arm's length markets on the one hand and hierarchies or vertical integration, on the other' (Porter, 1998). Therefore, two possibilities basically are left to the lawmakers who can:

- Require that the cluster self-appoints a 'representative' that will deal with tax authorities (nevertheless, the individuation of such a representative can be a cumbersome task for the cluster, unless its structure is based on the creation of a third separate entity, e.g., joint venture, European Economic Interest Grouping, etc.).

- Create a new legal form for SME clusters that provides them with legal personality and that includes the appointment of a representative for all administrative and tax purposes (this is the most radical and complex solution to the above problems and it would be suitable to have a common European initiative on that. In other words, the European lawmaker should take into account the phenomenon of clustering and should create new efficient and flexible corporate legal instruments aimed to enhance the competitiveness of cooperating SMEs).

In more general terms, it is possible to say that any reform aimed at extending the group taxation principles to SME clusters should take into account the nature of such a grouping with, more or less, innovative and radical solutions. Nevertheless, the Italian reform shows that there are no major legal barriers to the application of group taxation to clusters as, in practice, often they operate at least to a certain extent as a group and the integration and cooperation between its members prevails over competition. 
In a more general context, the national lawmakers should carefully take into account the possibility of dynamically applying tax tools traditionally developed for bigger business structures, including group taxation, to SME clusters, in order to create enablers to their further development and extra values from the synergies between its components. The reasons that justify our assumption are several in terms of benefits to the cluster. First of all, it is possible to expect a reduction of the overall income tax burden for the members of the cluster that, therefore, will have more resources for investments. To be more precise, the companies that make profits are expected to pay less tax, while the situation will not dramatically change for the members that report losses.

At the same time, a great simplification in the relations between the cluster and the tax authorities will be introduced because only one company will act before the tax authorities on behalf of the cluster by the appointment of the other members or by law, as specified above. Apart from this and from a more general perspective, the tax position of the companies in the cluster will be 'aligned' with the economic reality represented by the links between the cooperating firms and this would allow them to plan their activities and investments more rationally.

In the case of taxation, therefore, the objective of creating enablers for SME clusters can be reached through the extension of tools traditionally developed for bigger legal and business structures to smaller entities. As it will be shown in the next paragraph, the same goal can be exactly achieved, however in the opposite way, in the field of competition law.

\section{EU competition law}

EU competition law, in particular Article 81 EC Treaty, Article 82 EC Treaty and Merger Regulation (Council Regulation no. 139/2004 on the control of concentrations between undertakings, OJ L 24, 29.1.2004, pp.1-22), only applies to anti-competitive behaviours of companies with certain degree of market power, an approach traditionally similar, to a certain extent and from a partially different point of view, to the fiscal one discussed in the previous part. Although SMEs are not considered by the European Commission capable of infringing EU competition law, the issue of whether SME clusters as a 'new' form of economic entity (at least as regards the attention paid to it by the European policymakers) can infringe EU competition law is not clear. An interesting question that can be raised is whether the behaviours of SME clusters that have more market power than individual SMEs can invoke the application of the competition rules of the EU. Since the SME clusters have not included in the EU competition law practices, the answer to this question is not obvious. This part will examine from a positive point of view whether the three branches in EU competition law are applicable to the behaviours of SME clusters and if so, how.

\subsection{Article 82: abuse of dominant positions}

Article 82 deals with abusive behaviours of dominant undertakings, such as discrimination, predatory pricing, tying, marginal squeeze, denial of supply and so on. Three conditions are involved in the analysis of Article 82: 
1 the existence of a dominant position

2 abusive behaviours

3 effects on trade between member states.

The practices of Article 82 cases present two types of dominant position, single dominance and collective dominance. The former can be only held by one undertaking whereas the latter is collectively held by several undertakings (Jones and Sufrin, 2008). The analysis of the possibility of the application of Article 82 to SME clusters quite depends on the first condition, i.e., the existence of a dominant position. Without a dominant position can no undertaking infringe Article 82 .

First, the analysis of single dominant position looks at the market share. 'In the (European) Commission's decision-making practice, single dominance concerns normally arise in the case of undertakings with market shares of over 40\%' (paragraph 75 of Commission guidelines on market analysis and the assessment of significant market power, OJ C 165, 11.07.2002, pp.6-31). The discussion of whether an SME can be dominant under the meaning of Article 82, taking into account the small turnover of an SME (however, it should be noted that there may be in theory cases where SMEs have substantial market shares in niche markets) is normally out of the question. However, SME clusters may have more market power than individual SMEs. Can an SME cluster be considered a single undertaking and then dominant? The European authorities have not established a consistent approach on how several companies can be considered as a single undertaking (Monti, 2001). However, the most-often used method for the analysis of this issue lies in the concept of 'connected undertakings'. The European Commission puts its emphasis on control in the definition of connected undertakings. Simply speaking, A is connected to B as long as B has the power to exercise more than half of the voting rights of $\mathrm{A}$ or $\mathrm{B}$ has the power to appoint more than half of the members of A's supervisory board, board of management or bodies legally representing the undertaking or B has the right to manage A's affairs (Point 12 of Commission Notice on agreements of minor importance which do not appreciably restrict competition under Article 81(1), OJ C 368, 22.12.2001, pp.13-15).

Nevertheless:

"[C]lusters are geographical constellation of companies (producers, suppliers, services providers) and institutions (research laboratories, educational institutions and other institutions in a given economic field) co-located in a specific geographic location and linked through relations of interdependency and complementarily in providing a related group of products and/or services." (Effort Project, 2008)

Based on this definition, members of an SME cluster are connected first by geographical proximity and secondly by a production/service chain. The control-related connection does not appear in such a definition. Furthermore, when forming an SME cluster SMEs in practice 'are reluctant to enter into formal partnerships' and they also 'fear of losing the control of their enterprises' (European Commission, 2003). Consequently, an SME cluster is not organised in the way dictated by the concept of connected undertakings and hence an SME cluster cannot be considered as a single economic entity. Therefore, in no way can SME clusters violate Article 82 in terms of single dominance.

Secondly, it is interesting to examine whether members of an SME cluster can have collective dominant position. Based on the EU competition law practices, under certain 
conditions two or more independent economic entities, on a specific market, united by economic links, hold together a dominance position vis-à-vis the other operators in the same market. The analysis of collective dominant position focuses on a set of market features that are conductive to tacit collusion. The existence of these features produces a strong presumption of the presence of collective dominant position. The most important one of those market features is the existence of high entry barriers on the relevant market. It is generally accepted that collective dominance cannot be sustainable in a market with low entry barriers. The pressure of entry of potential competitors can easily collapse down collusion between undertakings. Because of the emphasis on high barriers to entry, collective dominance only targets anti-competitive behaviours on oligopolistic markets, such as telecommunications or PC operating system ones, where basically there are no SMEs involved (Buigues and Rey, 2004). Again, given the above definition of SMEs provided by the European Commission (Article 2.1 of Regulation 2003/361/EC), the ability of SME clusters to emerge on labour-intensive or capital-intensive markets is apparently limited and therefore, we cannot lead to a conclusion of high barriers to entry in the relevant market. Consequently, since SME clusters are present in a market with low barriers to entry, they are not likely to have a collective dominant position under Article 82.

\subsection{Merger regulation}

The EU Merger Regulation grants the European Commission the power to monitor concentrations, e.g., mergers, acquisitions and joint ventures, between undertakings. Can the formation of an SME cluster be caught by the EU Merger Regulation? It should be noted in advance that the EU Merger Regulation does not oblige all the concentrations to be notified and analysed by the European Commission, but it only requires so regarding concentrations where the turnovers of members involved are above a certain level. If the turnovers of the undertaking involved in a concentration do not exceed the prescribed level, the Merger Regulation is simply not applicable. So we will leave open the issues how an SME cluster is organised and whether the formation of an SME cluster can be regarded as a concentration under the Merger Regulation and take a look at the turnover-related thresholds within the Merger Regulation. If an SME cluster cannot meet those turnover-related thresholds, the Merger Regulation cannot apply to the formation of SME clusters, regardless how they are organised.

The Merger Regulation provides two turnover-related thresholds for obligatory notifications, which are (the full set of thresholds, which can be found at Article 1 of the Regulation, will not be quoted):

$$
\begin{aligned}
& \text { [...] the aggregate community-wide turnover of each of at least two of the } \\
& \text { undertakings concerned is more than EUR } 250 \text { million[...] } \\
& \text { [...]the aggregate community-wide turnover of each of at least two of the } \\
& \text { undertakings concerned is more than EUR } 100 \text { Million [...]. }
\end{aligned}
$$

However, as pointed out above, the European Commission defines SMEs as 'enterprises which employ fewer than 250 persons and which have an annual turnover not exceeding EUR 50 million and/or an annual balance sheet total not exceeding EUR 43 million'. Applying this definition to the turnover-related thresholds within the Merger Regulation, we would immediately reach a conclusion that neither of the two above-mentioned thresholds can be fulfilled. In conclusion, the formation of SME clusters, disregarding 
how they are horizontally or vertically organised, e.g., (hypothetically) through mergers, acquisitions or joint ventures, cannot be caught by the Merger Regulation.

\subsection{Article 81}

Article 81(1) prohibits all agreements between economic entities which may appreciably affect trade between Member States, unless those agreements can benefit from the exemption under Article 81(3). Classical anti-competitive agreements include price fixing, dividing territory, resale price maintenance, etc. (Jones and Sufrin, 2008). Article 81 is more relevant to the behaviours of SME clusters than Article 82 and the Merger Regulation. Reasons are two-fold. First, requirements of market power in the analysis of Article 81 are not as high as those in the analysis of Article 82 or Merger Regulation. Furthermore, in some cases market power is not even a concern under Article 81 since a simple inclusion of some anti-competitive clauses, the so called 'hardcore restrictions', can make the agreement concerned automatically void. Secondly, as we discussed above, members of SME clusters are connected mainly not through ownership or control, but through cooperation. The relationships between the members of an SME cluster are either suppliers and distributors or sellers and buyers or competitors. Hence the cooperation within SME clusters are usually embodied in all kinds of agreements, such as selling, distributing, research and development (R\&D), purchasing and so on, which exactly fall into the scope of Article 81, provided that the activities prohibited by Article 81 appear in those agreements. Furthermore, it should be pointed out that Article 81 is not intended to govern all anti-competitive agreements. Because of the 'rule of reason' contained in Article 81(3), the Commission adopted a series of documents that grant general exemption to categories of agreements, the so called 'block exemption'. These block exemptions quantify, with the help of market share thresholds, what is not a restriction of competition under Article 81, unless hardcore restrictions are contained. This section makes a brief introduction to those block exemptions.

In general two types of agreements are covered by block exemption regulations, which are vertical agreements and horizontal agreements. The parties to vertical agreements are at different levels in the production/service chain, while the parties to horizontal agreements operate at the same level in the production/service chain.

Pursuant to Article 3 of Commission Regulation no. 2791/1999 on the application of Article 81(3) to categories of vertical agreements and concerted practices (OJ L 336, 29.12.1999, pp.21-25), block exemption in general applies to vertical agreements where the market share of the supplier on the market where it sells the contract goods/services may not exceed $30 \%$. Nevertheless, where the agreement contains an exclusive supply obligation it is the buyer's market share on the market where it purchases the contract goods or services, which may not exceed the threshold of $30 \%$ in order for the block exemption to apply.

There is no single market share threshold for block exemption on horizontal agreements. The European Commission attaches different market-share thresholds to each category of horizontal agreements (Commission Notice Guidelines on the applicability of Article 81 of the EC Treaty to horizontal cooperation Agreements, OJ C 3, 6.1.2001, pp.2-30). There are four block exemptions relevant to the horizontal agreements of SME clusters: 
1 R\&D agreements (the combined market shares of the parties involved do not exceed $25 \%)$

2 production agreements (the combined market shares of the parties involved do not exceed $20 \%$ )

3 joint purchasing agreements (the combined market share of the parties involved do not exceed $15 \%$ both on the purchasing markets and on the selling markets)

4 commercialisation agreements (the combined market shares of the parties involved do not exceed $15 \%$ ).

Extra attention should be paid to agreements on standards for their lack of block exemption. The European Commission considers in the aforementioned Commission Notice Guidelines that ' $[\mathrm{h}]$ igh market shares held by the parties in the market(s) affected will not necessarily be a concern for standardisation agreement. Their effectiveness is often proportionate to the share of the industry involved in setting and/or applying the standard'. Therefore, even SME clusters can infringe Article 81 by signing agreements on standards under certain conditions.

Last but not least, hardcore restrictions refer to restrictions that are presumed to produce no economic benefits at all and consequently a simple inclusion of one or several hardcore restrictions may disentitle the benefit of block exemption. Nevertheless, a more specific introduction to hardcore restrictions is beyond the scope of this article (a full list of hardcore restrictions can be found at point 11 of de minimis Notice). Consequently, SME clusters must make sure that no hardcore restrictions are placed within the eventual agreements of cooperation.

\section{Conclusions}

The analysis carried out in the previous sections showed that both tax and competition law are likely to play a relevant role in the development and growth of SME clusters in Europe. Such a goal can nevertheless be reached in two different ways and precisely, as regards taxation, through the adoption of traditional tools, developed for bigger business entities, to clusters, notably the group taxation and for what concerns competition, through the non-extension of European antitrust regulations (especially Article 82 EC Treaty and the Merger Regulation) to cooperating SMEs. The European and national lawmakers should take into account the possibility of rethinking the notion of group taxation to different entities, like SME clusters, not characterised by a strong vertical integration and on the other hand, should be aware that the lack of such vertical integration and the very structure of SME clusters do not make feasible the applicability of legal tools aimed to enhance competition in the market. With this regard, EU competition law, in particular Article 82 and Merger Regulation, in most cases may not affect the evolution of SME clusters that are free to choose the most suitable form to organise and develop themselves. Nevertheless, SMEs should always keep in mind that their cooperation should not infringe Article 81 and this provision is relevant for all companies - clustered or not - and therefore it does not act as barrier or enabler in particular for clustering. 
From a more general perspective, then, one of the conclusions proposed consists of a question about the evolution of the clusters and the impact that legal requirements and regulations will have on that. It is arguable, in fact, whether the concept of cluster will continue to be predominantly dominated, as pointed out above, by the horizontal integration between its members, as stressed out in the literature, especially by Porter, according to which 'clusters mitigate the problems inherent in arm's length relationships without imposing the inflexibilities of vertical integration or the management challenges of creating and maintaining formal linkages such as networks, alliances and partnerships' and, therefore, 'a cluster of independent and informally linked companies and institutions represents a robust organisational form that offers advantages in efficiency, effectiveness and flexibility' (Porter, 1998).

The legal reforms that have been implemented in Italy (and that can be successfully adopted by other jurisdictions) in particular, do show that a more formal structure is to a certain extent necessary for the cluster in order to get more benefits in terms of efficiency and costs savings. From the legal perspective, it is not very convincing the statement that 'clusters are also a better alternative to vertical integration' and that 'although extensive vertical integration may have once been the norm, a fast-changing environment can render vertical integration inefficient, ineffective and inflexible' (Porter, 1998).

Provided that the notion of control is basically inconsistent with that of clustering, it is possible to expect that the future of many clusters will lie in between vertical and horizontal integration, so that the cluster itself will be, to a certain extent, structured like a pyramid with an extremely wide base. The top of this hypothetic structure will have the duty not to control the other members, but to represent them before the 'external world', such as tax and competition authorities, when necessary. The mechanisms to create such a structure are left primarily to the companies that are involved in the cooperation and then, on a bigger scale, to the policymakers. Such re-organisation would allow clusters to benefit mostly from taxation tools while, at the same time, avoiding the constraints arising from competition law.

\section{References}

Aernoudt, R. (2003) European Enterprise Policy. From SME Policy to Entrepreneurship Policy, Intersentia, Antwerp.

Bagnasco, A. (1977) The Three Italies, Il Mulino, Bologna.

Buigues, P. and Rey, P. (2004) The Economics of Antitrust and Regulation in Telecommunications, Edgard Elgar Publishing, Cheltenham.

Callegati, E. and Grandi, S. (2005) 'Cluster dynamics and innovation in SMEs: the role of culture', working paper No. 3, Torino, Università di Torino, available at http://www.eblacenter.unito.it/WP/2005/3_WP_Ebla.pdf (accessed on 16 July 2008).

Cardi, P., Cilento, M., Coppola, D., Guerrieri, P., Ripa, E. and Zanchiello, C. (2006) L'Evoluzione Normativa dei Distretti Industriali, Stoa, Napoli.

Effort Project (2008) WP1: Conceptual Framework and Methodology-Deliverable D 1.1 Conceptual Framework, available at http://www.effortproject.eu/component/option,com_docman/task,cat_view/gid,14/Itemid,32 (accessed on 25 and 29 July, 2008).

European Commission (2003) Observatory of European SMEs 2003. SMEs and Cooperation', available at http://ec.europa.eu/enterprise/enterprise_policy/analysis/doc/smes_observatory_2003_report5_ en.pdf (accessed on 23 July 2008). 
European Commission (2006) Common Consolidated Corporate Tax Base Working Group, $\mathrm{CCCTB} / \mathrm{WP} / 035 / \mathrm{doc} / \mathrm{en}$, available at http://ec.europa.eu/taxation customs/resources/documents/taxation/company tax/ common_tax_base/CCCTBWP057_en.pdf (accessed on 15 July 2008).

European Commission (2008) Think Small First. A Small Business Act for Europe, SEC(2008) 2101, SEC(2008) 2102, available at http://eur-lex.europa.eu/LexUriServ/LexUriServ.do?uri=COM:2008:0394:FIN:EN:HTML (accessed on 15 July 2008).

Eurostat (2008) Enterprises by Size Class - Overview of SMEs in the EU, available at http://epp.eurostat.ec.europa.eu/cache/ITY_OFFPUB/KS-SF-08-031/EN/ KS-SF-08-031-EN.PDF (accessed on 15 July 2008).

Jarass, L. and Obermeir, G.M. (2006) 'A proposal for the efficient taxation of all business income in the EU', Intereconomics, Vol. 41, No. 3, pp.151-158.

Jones, A. and Sufrin, B. (2008) EC Competition Law: Text, Cases and Materials, Oxford University Press, Oxford.

Lenoci, F., Malerbi, G. and Peola, S. (2006) Riforma dei Distretti Industriali e Basilea 2, Wolters Kluwer Italia, Milano.

Monti, G. (2001) 'The scope of collective dominance under Article 82 EC', Common Market Law Review, Vol. 38, No. 1, pp.131-157.

Parrilli, D. (2008) 'Profilo tributario delle holding olandesi: il regime della participation exemption tra passato e futuro', Diritto e Pratica Tributaria Internazionale, No. 1, pp.309-338.

Pinto Barcellos, P.F., Galelli, A., Mueller, A., dos Reis, Z.C. and Gonzatto Peretti, J.L. (2008) 'Collaborative networks: an innovative approach to enhance competitiveness of small firms in Brazil', in K. Thoben et al. (Eds.): Proceedings of the 14th International Conference on Concurrent Enterprising ICE 2008, Centre for Concurrent Enterprise Nottingham: University of Nottingham, pp.211-216.

Porter, M.E. (1998) 'Clusters and the new economics of competition', Harward Business Review, Vol. 76, No. 6, pp.77-91.

Vermeulen, E. (2003) The Evolution of Legal Business Forms in Europe and the United States, Kluwer Law International, Alphen aan den Rijn. 